\title{
Peran Guru dalam Mengantisipasi terjadinya Pelecehan Seksual terhadap Tunagrahita Ringan
}

\author{
Massuhartono $^{1 *}$ \& Sauqi Rahma Putri ${ }^{2}$ \\ Universitas Islam Negeri STS Jambi, Muaro Jambi \\ *Email: massubartono@uinjambi.ac.id
}

\begin{abstract}
ABSTRAK
Peran guru bagi anak kebetuhan khusus meliputi informator, organisator, motivator, inisiator dan fasilitator. Peran ini sebagai upaya guru dalam membimbing peserta didiknya agar dapat mencapai kemandirian dan bisa melindungi dirinya. Padca prosesnya, masih banyak guru yang kesulitan memahamkan ABK dalam pendidikan seksual. Hal ini dikarenakan kurangnya pelatihan bagi guru dalam pengetahuan tentang seks, Keterbatasan yang dialami peserta didik dan peran orang tua yang kurang koperatif terhadap perkembangan anaknya. Melalui pendekatan kualitatif, disimpulkan bahwa implikasi penelitian ini dapat dijadikan refensi mengenai peran dan metode bimbingan bagi guru anak kebutuhan khusus dalam memberikan bimbingan kepada peserta didiknya. Upaya yang dilakukan oleh guru ini dapat membantu peserta didik dalam mencapai kemandirian dan bisa melindungi dirinya.
\end{abstract}

Kata Kunci : Peran Guru; Pelecehan Seksual; Tunagrahita Ringan.

\section{ABSTRACT}

The teacher's role for children with special needs includes information, organizer, motivator, initiator, and facilitator. This role is the teacher's effort in guiding their students to achieve independence and protect themselves. In the process, there are still many teachers who have difficulty understanding $A B K$ in sexual education. Is due to the lack of training for teachers in knowledge about sex, limitations experienced by students, and the role of parents who are less cooperative with their children's development. Through a qualitative approach, it is concluded that this research's implications can be used as a reference regarding the role and methods of guidance for special needs children teachers in guiding their students. The efforts made by this teacher can belp students achieve independence and can protect themselves.

Keywords : The teacher's Role; Sexual Harassment; Mild Mental Retardation 
Massuhartono., S.R. Putri.

\section{PENDAHULUAN}

Pendidikan adalah hak bagi setiap warga negara yang secara eksplisit tercantum dalam Undang-undang Dasar 45. Pada pasal 31 ayat 1 disebutkan bahawa "setiap warga negara berhak mendapatkan pendidikan". Hal ini menegaskan bahwa bagi seluruh warga negara Indonesia, telah di jaminan untuk mendapatkan akses pendidikan, termasuk mereka yang mempunyai keterbatasan fisik, ekonomi, maupun keterbatasan mental. Keterbatasan mental bukanlah menjadi alasan untuk mendapatkan pendidikan. Sebab hal ini telah di atur dalam UU tentang Sistem Pendidikan Nasional no.20 tahun 2003 disebutkan bahwa: "pendidikan khusus merupakan pendidikan karena kelainan fisik, emosional, mental dan sosial (Effendi, 2006: 1).

Keterbatasan mental yang di alami banyak anak di Indonesia menjadi tugas utama Sekolah Luar Biasa (SLB). Dalam menjalankan tugasnya, SLB dituntut untuk dapat membantu anak berkebutuhan khusus agar mencapai perkembangan yang optimal sesuai dengan tingkat dan jenis anak berkebutuhan masing-masing (Santoso, 2012: 11). Indikator utama siswa berkebutuhan khusus telah berhasil mencapai perkembangan secara optimal, apabila ia dapat menggunakan kemampuannya dengan baik sesuai dengan derajat keterbatasannya. Faktanya, saat ini masih banyak ditemukan ketidaksesuaian dalam membantu anak berkebutuhan khusus untuk mencapai perkembangan tersebut. Ketidaksesuaian tersebut diantaranya masih banyaknya ditemukan anak berkebutuhan khusus yang ketika berada di rumah belum mampu melakukan aktivitas sehari-hari, padahal pada saat sekolah ia mampu melakukan aktivitas itu.

Ketidakmampuan tersebut tidak semata-mata karena keterbatasan yang mereka alami, tetapi dapat juga disebabkan oleh ketidakmampuan guru dalam membimbing anak berkebutuhan khusus secara individu hingga ia dapat mengetahui berbagai kendala yang di hadapi. Oleh karena itu, perlu adanya upayakan dalam membantu meraka untuk mengatasi berbagai kendala tersebut. Salah satunya adalah diberikan bimbingan dan konseling melalui proses pembelajaran (Purwanta, 2012: 9).

Sebagai subjek pendidikan, anak berkebutuhan khusus adalah pribadipribadi yang unik baik secara pribadi maupun dengan keterbatasannya. Jika dilihat dari kecacatannya, masing-masing anak memiliki karakteristik yang merupakan sumber perbedaan anatar satu dengan lainnya. Hal inilah yang menjadi alasan perlunya layanan yang berbeda dari masing-masing anak, seperti halnya pada anak tunagrahita ringan (Purwanta, 2012: 14).

Kemandirian merupakan kunci utama bagi anak berkebutuhan khusus dalam mengatasi kesulitan yang ia alami. Menurut Warati, yang dimaksud dengan kemandirian disini adalah suatu sifat, sikap, ataupun kondisi yang mampu untuk 
Peran Guru dalam Mengantisipasi Terjadinya Pelecehan Seksual Terhadap Tunagtahita Ringan melakukan sesuatu yang biasa untuk dilakukan tanpa memerlukan bantuan orang lain. Mengatasi kesulitan dalam aktivitas sehari-hari merupakan salah satu bentuk kemandirian anak. Maka disinilah letak pentingnya layanan bimbingan dan konseling bagi anak (Warati dan Juhar, 2015: 4).

Sekolah Luar Biasa (SLB) Sri Soedewi ini merupakan lembaga pendidikan bagi anak berkebutuhan khusus. Sekolah ini terdiri dari beberapa kelas meliputi kelas tunanetra, tunarungu, tunadaksa, dan tunagrahita. Sekolah ini mencakupi jenjang pendidikan mulai dari TK, SD, SMP, dan SMA. Proses pembelajaran di Sekolah tersebut memang memiliki kurikulum yang sudah ditentukan. Akan tetapi dalam hal pembelajaran bagi anak kebutuhan khusus (tunagrahita) bukanlah hal perkembangan potensi yang lebih diutamakan melainkan seorang anak dapat mencapai kemandirian.

Sebagai sekolah bagi anak berkebutuhan khusus SLB Sri Soedewi berupaya mencapai tujuan pendidikan khusus yaitu berkembangnya kepribadian dari setiap anak secara optimal. Indikator optimal ini adalah kemampuan mengurus diri sendiri, namun bagi siswa yang mengalami kelainan fisik indikator optimal dapat berupa mendekati ciri-ciri kepribadian yang sesuai dengan kebutuhan diri dan lingkungannya. Serta tujuan lain pembelajaran atau bimbingan bagi anak kebutuhan khusus adalah untuk dapat melindungi dirinya agar terhindar dari tindakan susila seperti pelecehan seksual dan sebagainya, dalam anak tunagrahita dikenal dengan program pengembangan diri (Purwanta, 2012: 10). Selain itu dapat berguna bagi anak tunagrahita ringan agar mencapai kemandirian serta dapat melindungi dirinya, seperti dalam hal dapat terhindar dari pelecehan seksual (Kustawan dan Lisnanawati, 2014: 7).

Di Indonesia pelecehan seksual semakin banyak terjadi, meliputi pemerkosaan, sodomi, pedofil (Yuwono, 2015: 44) serta pornografi dan lain sebagainya yang mana salah satu yang menjadi objek adalah anak berkebutuhan khusus seperti tunagrahita ringan. Di Indonesia pornografi di atur dalam UU No. 44 Tahun 2008. Pada Pasal 1 angka 1 disebutkan bahwa "Pornografi adalah gambar, sketsa, ilustrasi, foto, tulisan, suara, bunyi, gambar bergerak, animasi, kartun, percakapan, gerak tubuh, atau bentuk pesan lainnya melalui berbagai bentuk media komunikasi dan/atau pertunjukan di muka umum, yang memuat kecabulan atau eksploitasi seksual yang melanggar norma kesusilaan dalam masyarakat"(Maslihah, 2013: 24). Dalam salah satu media massa Ketua Lembaga Perlindungan Saksi dan Korban (LPSK), Abdul Haris menyebutkan "hingga maret 2017 terlapor 127 kasus kekerasan seksual, 51\% terjadi pada anak-anak salah satunya anak berkebutuhan khusus." Seperti disebutkan dalam berita nasional "pada 2013 di Garut seorang guru olahraga SLB mencabuli 5 siswa SLB”. Contoh lain pada 2014 di Bogor seorang guru dan terapis mencabuli 8 siswa SLB. (Hazliansyah: 2013: 27)

Di SLB Sri Soedewi dalam rentang waktu 2017-2018 terdapat kasus 
pelecehan seksual. Salah satu anak yang dikeluarkan karena ketahuan melakukan sodomi terhadap temannya, kasus lain seorang siswa melakukan pelecahan terhadap temannya di lingkungan sekolah. selain itu baru-baru ini di sekolah mengadakan razia handphone ternyata banyak anak-anak yang kedapatan menyimpan dan menonton konten-konten yang mengandung unsur pornografi.

Penelitian ini akan difokuskan pada wali kelas dan peserta didik tunagrahita ringan di SLB N Sri Soedewi Jambi. Dalam penelitian ini penulis menggunakan jenis pendekatan kualitatif, yang mendiskripsikan data di lapangan apa adanya. Proses pengumpulan data dalam penelitian ini menggunakan tiga cara yang dilakukan secara berulang-ulang agar keabsahan datanya dapat dipertanggung jawabkan, Untuk mendapatkan data yang akurat dalam penyusunan skripsi ini, peneliti menggunakan beberapa metode antara lain: Observasi, wawancara, dan dokumentasi.

\section{LANDASAN TEORITIS}

Penelitian ini bertujuan untuk melihat dan menjelaskan bagaimana peran guru bagi anak tunagrahita ringan, maka dari itu terdapat beberapa teori yang dijadikan landasan dalam penelitian ini, Landasan teori yang digunakan dapat dijabarkan dalam beberapa teori yaitu teori peran, guru,pelecehan seksual, dan tunagrahita yang akan diuraikan sebagai berikut:

Pertama, dalam Kamus Besar Bahasa Indonesia kata "peran" diartikan sebagai beberapa tingkah laku yang diharapkan dimiliki oleh orang yang berkedudukan dimasyarakat (Anonim,1998: 84). Sedangkan Ahmadi mendefinisikan peranan sebagai suatu kompleks pengharapan manusia terhadap caranya individu harus bersikap dan berbuat dalam situasi tertentu berdasarkan status dan fungsi sosialnya (Ahmadi, 2002: 115). Kedua, secara bahasa kata "guru" berasal dari bahasa sansekerta, "guru" berarti mulia, bermutu, memiliki kehebatan dan orang yang sangat dihormati. Pada kamus bahasa jawa kuno kata "guru" berarti orang yang patut dimuliakan, pembimbing (spiritual). (Zen, 2006: $10)$.

Ketiga, pelecehan seksual. Trwijati menjelaskan bahwa pelecehan seksual merupakan perilaku yang bersifat seksual yang tidak diinginkan dan tidak dikehendaki oleh penerima atau korbanya dan berakibat mengganggu diri penerima pelecehan, perilakunya yang dapat digolongkan sebagai tindakan pelecehan seksual seperti pemaksaan melakukan kegiatan seksual, pernyataan merendahkan yang berorientasi seksual atau seksualitas, lelucon yang berorientasi seksual, permintaan melakukan tindakan seksual yang disukai pelaku dan juga ucapan atau perilaku yang berkonotasi seksual, tindakan-tindakan tersebut dapat disampaikan secara langsung maupun tidak langsung (implicit) (Trwijati, 1).

Keempat, tunagrahita. Adalah sebuah istilah yang digunakan untuk 
Peran Guru dalam Mengantisipasi Terjadinya Pelecehan Seksual Terhadap Tunagtahita Ringan menyebut anak yang mempunyai kemampuan intelektual di bawah rata-rata. Dalam kepustakaan bahasa asing digunakan istilah-istilah mental retasdation, mentally retarded, mental deficiency, mental defective, dan lain-lain. Istilah tersebut sesungguhnya mempunyai arti yang sama yang menjelaskan kondisi anak yang kecerdasanya jauh di bawah rata-rata dan ditandai oleh keterbatasan intelegensi dan ketidak cakapan dalam interaksi sosial. Adapun kategori anak tunagrahita ini meliputi tunagrahita ringan, sedang dan berat (Desiningrum, 2016: 16).

\section{HASIL DAN PEMBAHASAN}

\section{Peran Guru Bagi Tunagrahita Ringan}

Dalam menjalankan tugas mendidik dan membimbing anak kebetuhan khusus, guru-guru di SLB Sri Soedewi memiliki berbagai peran yang meliputi peran sebagai informator, organisator, motivator, inisiator dan fasilitator. Berbagai peran ini dilaksanakan dalam upaya guru membimbing peserta didiknya agar dapat mencapai kemandirian dan bisa melindingi dirinya. Namun demikian, masih ada guru yang mengalami kendala dalam melakukan proses pembelajaran maupun bimbingan khususnya pengetahuan tentang seks. Hal ini disebabkan kurangnya pelatihan bagi guru dalam pengetahuan tentang seks, serta masih ada guru yang mengalami kesulitan dalam memahami peserta didiknya. Selain itu karena keterbatasan yang dialami peserta didik juga menjadi kendala bagi guru dalam memberikan bimbingan. Begitu juga dengan orang tua yang kurang koperatif terhadap perkembangan anaknya juga menjadi kendala tersendiri. Untuk lebih jelas bagaimana peran guru SLB Sri Soedewi Jambi dalam mengantisipasi terjadinya pelecehan seksual pada tunagtahita ringan, akan diuraikan sebagai berikut:

Pertama, Peran informator. Sebagai informator guru harus memahami kosakata dasar (Febrisma, 2013: 112) dalam menyeleksi informasi-informasi apa saja yang dapat ditangkap oleh peserta didik, karena anak ini kesulitan terhadap hal-hal yang abstrak. Dalam menjalankan peran sebagai informator, guru tunagrahita ringan lebih banyak menggunakan media seperti halnya ketika menjelaskan pengenalan anggota tubuh, ( Al Irsyadi dan Nugroho, 2015: 20) tata cara menggosok gigi, memasang kancing baju, menyisir rambut, mencuci tangan, pengenalan rambu-rambu lalu lintas, cara menyeberangi jalan dan lain sebagainya.

Kedua, Peran organisator. Seperti hal nya dengan guru-guru yang lain, guru di SLB Sri Soedewi juga melakukan perannya sebagai seorang organisator. Mereka harus mampu mengelola kegiatan yang bersifat akademik, maulai dari menyiapkan silabus, mengadakan workshop, menyususn jadwal pelajaran dan lain sebagainya. Segala sesuatu yang berkaitan dengan proses belajar - mengajar harus di organisasiskan seefektif dan seifisien mungkin dan disesuiakan dengan kemampuan siswanya. Akan tetapi perlu di ingat bahwa untuk anak tunagrahita 
Massuhartono., S.R. Putri.

ringan mereka memiliki nmasalah dengan mental. Maka dalam proses pembelajaran perlukan diakukan assesmen terlebih dahulu, hal ini berguna untuk melihat potensi dari peserta didik (Humaira, 2012: 96). Selain itu guru juga dituntut untuk mampu untuk mengenali dan memahami keadaan dan kebutuhan serta kemampuan dari peserta didik, hal ini agar dapat menerapkan metode pembelajaran yang sesuai dan tepat.

Ketiga, Peran motivator. Untuk mencapat hasil pembelajar yang optimal, guru di SLB Sri Soedewi dituntut untuk kreatif dalam membangkitkan motivasi belajar siswanya. Hal ini bertujuan untuk terbentuk perilaku belajar siswa yang mandiri. Dalam rangka meningkatkan motivasi belajar siswa ini, guru harus mampu menjelaskan dengan baik tujuan yang ingin dicapai dari proses pembelajaran. Sebab, tujuan pembelajaran yang jelas dapat membantu siswa memahami ke mana ia ingin dibawa. Hal ini akan bermuara pada tumbuhnya minat belajar siswa dan pada saatnya dapat meningkatkan motivasi belajar mereka. Semakin mereka memahami tujuan pembelajaran yang ingin dicapai, maka akan semakin kuatpula motivasi belajar mereka. Selain itu dalam rangka meningkatkan motivasi siswanya, guru di SLB Sri Soedewi juga dituntut untuk mampu membangkitkan minat siswa baik pembelajaran amuapun kegiatan lainya, menciptakan suasana pembelajaran yang menyenangkan, memberikan reward dan punishment yang wajar serta menciptakan kerja sama antar siswanya.

Keempat, Peran pasilitator. Didalam kelas sebagai guru harus mampu untuk menjadi fasilitator yang baik. Hal ini bertujuan untuk dapat menciptakan lingkungan kelas dan suasana belajar yang nyaman bagi peserta didik. Selain untuk tranfer ilmu guru juga harus memfasilitasi peserta didiknya agar dapat mencapai kemandiriannya. Yang dimaksud dengan peran guru sebagai pasilitator adalah memberikan fasilitas ataupun kemudahan-kemudahan dalam pelaksanaan belajar - mengajar. Fasilitas tersebut dapat berupa menciptakan suasana pembelajaran yang sedemikian rupa, serta sesuai dengan perkembangan siswa. Sehingga interaksi dalam proses belajar - mengajar akan berlangsung secara efektif dan efisien. Hal ini tentunya sesuai dengan semboyan "Tut Wuri Handayani". (Desmita, 2015: 4)

\section{Upaya Guru Dalam Mengantisipasi Terjadinya Pecehan Seksual Bagi Anak Tunagrahita}

Mengantisipasi terjadinya pecehan seksual bagi anak tunagrahita, guru di SLB Sri Soedewi menjalankan berbagai macam program dan pelatihan. Programprogram ini disusun tidak secara eksplisit untuk mengantisipasi pelecehan seksual saja, namun lebih dari itu untuk mencapai kemadirian anak. Program ini disebut dengan program pengembangan diri bagi anak tunagrahita. Adapun program tersebut antara lain:

Pertama, keterampilan merawat diri. Merawat diri merupakan 
Peran Guru dalam Mengantisipasi Terjadinya Pelecehan Seksual Terhadap Tunagtahita Ringan keterampilan dasar bagi anak tunagrahita/ keterbelakangan mental (Yosiani, 2014: 112) dalam merawat dirinya. Tata cara merawat diri mulai dari hal-hal yang bersifat sederhana, seperti tata cara menggosok gigi (dengan memberikan contoh secara langsung akan lebih efektif), tata cara mandi (menjelaskan alat yang digunakan dan cara penggunaannya seperti sabun mandi, sampo, sabun cuci piring dan lain sebaginya), membersihkan telinga, dan hal lain sebagainya."

Kedua, Keterampilan menjaga keselamatan dan kesehatan. Keterampilan ini dibutuhkan untuk menjada dan melindungi individu yang bersangkutan dari penyakit dan bahaya. Contohnya perlindungan dari pelecehan seksual, Maka dari pihak sekolah melalui guru-guru dan instansi-instansi (PKBI/Persatuan Keluarga Berencana Indonesia, IWAPI/Ikatan Wanita Pengusaha Indonesia dan sebagainya) terkait untuk pengenalan pendidikan seks bagi anak tunagrahita.

Ketiga, Keterampilan berkomunikasi. Bagi peserta didik tunagrahita mereka harus memiliki keterampilan berbahasa baik secara verbal maupun tertulis dalam berkomunikasi. Termasuk dalam menyampaikan pesan, keinginan atau perasaan baik secara verbal maupun alat bantu komunikasi misalnya picture ecchange communication system (pecs) (Cangara, 2012: 11). Komunikasi antara guru dan peserta didik harus terjalin secara emosional karena guru harus mampu melihat dan mengenali gejala-gejala dari perilaku peserta didik seperti ketika ada yang tertarik dengan teman lawan jenisnya."

Keempat, Keterampilan bersosialisasi. Merujuk pada keterampilanketerampilan yang dibutuhkan peserta didik tunagrahita dalam menjalin interaksi dengan orang lain (Desiningrum, 2016 :16). Guru harus mampu untuk memberikan bimbingan bagi peserta didik tunagrahita dalam bagaimana cara bersosialisasi dengan orang lain (Putri, 2012: 320). Cara bersosialisasi ini guru juga memberikan penjelasan apa saja yang boleh dan tidak boleh dilakukan oleh peserta didik dalam bersosialisasi. Seperti halnya ketika peserta didik bersosialisasi dengan temannya khususnya pada lawan jenis apa saja yang boleh dilakukan dan tidak boleh dilakukan.

Kelima, Keterampilan kerja. Keterampilan ini diberbedakan dengan keterampilan vokasi. Keterampilan bekerja merupakan keterampilan yang mendukung kesuksesan anak tunagrahita dalam pekerjaannya. Berbeda dengan keterampilan vokasi yang merupakan keterampilan untuk mendukung anak tunagrahita untuk menguasai satu jenis pekerjaan saja, semisal keterampilan untuk pekerjaan laundry. Keterampilan ini bertujuan agar setelah lulus peserta didik memiliki kemampuan atau keterampilan untuk melakukan pekerjaan yang sesuai dengan keahliannya (Kustawan dan Lisnanawati, 2014: 8).

Keenam, Keterampilan menggunakan waktu luang. Keterampilan ini bertujuan agar anak tunagrahita mampu menggunakan waktu luangnya untuk kegiatan yang lebih kreatif yang di sesuaikan dengan usia perkembangannya. Keterampilan ini berupa keterampilan bermain, baik sendirian maupun ketika 
Massuhartono., S.R. Putri.

bersama degan teman, di sekolah maupun lingkungan rumahnya.

Ketujuh. Melatih Kemandirian (Kustawan dan Lisnanawati, 2014: 8) Guru sebagai pembimbing khususnya bagi anak tunagrahita lebih menekankan pada tahap kemandirian siswa, apabila siswa dapat mencapai kemandiriannya hal utama yang ditekankan adalah cara perlindungan diri dari segala bahaya yang akan ditemuinya seperti cara mengenal rambu lalu lintas, melindungi diri dari pelecehan seksual dan lain sebagainya. Kemandirian bagi anak tunagrahita digunakan tujuan utama bagi peserta didik dalam mengenal diri sendiri dan lingkungannya sebagaimana adanya, fungsi kemandirian ini meliputi kemampuan pengenalan terhadap keadaan, potensi, kecenderungan, kekuatan dan kelemahan diri sendiri seperti apa adanya. Kemudian menerima diri sendiri/ pemahaman diri (Hikmawati, 2011: 47).

Dalam menjalankan program dan pelatihan ini, guru di SLB Sri Soedewi menggunakan beberapa metode dan pendekatan, yaitu: Pertama, menggunakan metode pembelajaran. Metode ceramah sejak dulu digunakan sebagai alat komunikasi lisan antara guru dan peserta didik dalam interaksi edukatif. Meski metode ini lebih banyak menuntut keaktifan guru daripada peserta didik, tetapi tetap tidak bisa ditinggalkan begitu saja dalam kegiatan pembelajaran. Keberhasilan metode ini harus didukung alat bantu lainnya seperti gambar, foto, benda, barang tiruan dan sebagainya (Elly, 2013: 166) Guru menggunakan metode ini dalam proses pembelajaran, terlebih mengenai pengetahuan tentang seks guru menggunakan metode ini untuk memberikan pengetahuan umum yang berkaitan dengan seks. Hal ini dilakukan secara berlang-ulang karena anak tunagrahita ini harus dilakukan penjelasan yang berulang-ulang agar dapat disimpannya.

Kedua, metode proyek. Metode ini menekankan pada penyajian pelajaran yang berangkat dari dari suatu masalah, kemudian cari sumber permasalahannya dari berbagai aspek lalu kemudian dicari solusinya. (Kustawan dan Lisnanawati, 2014: 10) Memberikan bimbingan bagi tunagrahita harus secara detail, karena terkadang kemampuan mereka berbeda-beda. Dalam penjelasan tentang pengetahuan seks misalnya sebagai seorang guru harus menjelaskan dengan katakata yang tepat dan jelas. Biasanya ada suatu masalah yang berkaitan dengan pelecehan seksual, maka guru harus memberikan penjelasan secara detail akan hal tersebut.

Ketiga, metode diskusi. Diskusi adalah memberikan alternatif jawaban untuk membantu memecahkan berbagai masalah kehidupan. Metode diskusi (Kustawan dan Lisnanawati, 2014: 10) juga digunakan guru dalam memberikan bimbingan mengenai pengetahuan tentang seks. Hal ini dilakukan dengan cara peserta didik diberi kesempatan untuk mengungkapkan permasalahannya (terlebih tentang pengetahuan seks seperti apa itu mimpi basah, kenapa perempuan haid dan hal terkait lainnya). Setelah peserta didik mengungkapkan 
Peran Guru dalam Mengantisipasi Terjadinya Pelecehan Seksual Terhadap Tunagtahita Ringan permasalahannya kemudian guru memberikan jawaban dengan bahasa yang singkat, jelas dan tepat serta diulang-ulang agar dapat dipahami oleh peserta didik.

Keempat, metode demonstrasi. Demonstrasi adalah suatu metode yang digunakan untuk memperlihatkan suatu proses atau cara kerja suatu benda yang berkenaan dengan bahan pelajaran (Kustawan dan Lisnanawati, 2014: 11). Metode ini menghendaki guru lebih aktif dari pada peserta didik. Sebagai guru dalam pengetahuan tentang seks juga sering digunakan media yang langsung berkaitan, Seperti halnya guru terkadang menggunakan menggunakan vidio animasi, gambar-gambar dan lain sebagainya.

Kelima, menggunakan prinsip-prinsip pembelajaran tunagrahita. Ada tiga prinsip pokok pembelajaan bagi anak tunagrahitayaitu: (1) prinsip kasih sayang. Mengajar peserta didik dengan tunagrahita harus penuh dengan kesabaran dan penuh kasih sayang. Guru tidak boleh memaksakan materi pelajaran pada siswa tunagrahita, karena hal tersebut dapat membuat siswa mudah frustasi (Pantjastuti, 2017: 6) Sebagai contoh, ada kasus dimana salah satu siswi yang sedang menstruasi melepaskan pembalutnya di toilet kemudian dibuang sembarangan. Maka dari itu guru perlu memegang prinsip ini dalam melakukan bimbingan bagi peserta didik. (2) Prinsip Keperagaan. Kesulitan utama anak tunagrahita di bidang akademik disebabkan oleh kesulitan mereka dalam berpikir abstrak. Dalam pembelajaran hendaknya peserta didik mengalami pengalaman langsung (Pantjastuti, 2017: 6). Dengan berada di situasi dan lingkungan yang dimaksud atau dengan penggunaan alat peraga, terlebih mengenai pengetahuan seks guru menggunakan alat peraga dan gambar-gambar reproduksi dengan bahasa yang singkat, tepat atau tidak menggunakan majas. (3) Prinsip habilitasi dan rehabilitasi. Prinsip ini bertujuan mengembangkan potensi peserta didik, meski kemampuan tersebut terbatas dan usaha untuk mengembalikan kemampuan yang hilang atau berfungsi secara optimal, meskipun mengalami hambatan dalam hal akademik, guru hendaknya mencari potensi lain dari peserta didik tunagrahita (Pantjastuti, 2017: 7). Apabila potensi itu ditemukan guru dapat mengembangkannya secara optimal. Selain itu guru juga harus mampu untuk melihat gejala-gejala perilaku dari peserta didik terlebih berkaitan dengan gejalagejala yang berkaitan dengan pelecehan seksual. Maka dari itu guru harus bekerja sama dengan guru-guru lain yang ada di sekolah dan orangtua peserta didik.

Keenam, bekerja sama dengan instansi-instansi terkait. Sekolah menjalankan perannya dalam mengembangkan potensi dan pengetahuan peserta didik (Nandadkk, 2014: 561) salah satunya dengan cara melakukan kerja sama dengan instansi-instansi yang dapat memberikan informasi-informasi baru yang diperlukan oleh peserta didik. Instansi-instansi ini meliputi instansi kesehatan, ketenagakerjaan, kewirausahaan, pertanian, peternakan dan lain sebagainya. Untuk materi tentang seks biasanya itu datang dari instansi-instamsi kesehatan 
Massuhartono., S.R. Putri.

seperti dari puskesmas, anak kesehatan UNJA, PKBI dan lain sebagainya. Biasanya kalau untuk materi pengetahuan seks ini instansi-instansi itu buat dalam bentuk seminar, biasanya banyak menggunakan media seperti video, alat peraga, dan gambar-gambar. Sebenarnya kalau bekerja sama dengan instansiinstansi merupakan program dari pemerintah pusat, namun terkadang ada juga yang dari sekolah.

\section{Faktor Penghambat Guru dalam Menjalankan Perannya}

Ada beberapa faktor penghambat guru SLB Sri Soedewi dalam menjalankan perannya, meliputi: pertama, dilihat dari peserta didik. Berdasarkan pada hambatan-hambatan yang dialami oleh peserta didik tunagrahita, maka masalah tersebut menjadi salah satu kendala yang dialami oleh guru dalam memberikan bimbingan kepada peserta didiknya (Rofiah: 259). Hal ini dikarenakan sering terjadi kesalahan menerima informasi yang diberikan sehingga peserta didik salah menerapkannya. Berkaitan dengan pengetahuan tentang seks, guru sering terkendala dengan penggunaan kosakata yang akan digunakan dalam menyampaikan pesannya. Hal ini disebabkan karena peserta didik mengalami kesulitan dalam menangkap kosakata yang baru, sehingga guru harus melakukannya dengan berulang-ulang. Guru dalam menyampaikan pesan kepada peserta didik harus menggunakan bahasa yang tepat/ tidak menggunakan majas, singkat (tidak berbelit) dan harus dapat dipahami oleh peserta didik dengan baik dan benar, agar terhindar dari salah mengartikan. Hal ini dikarenakan tingkat libido anak tunagrahita lebih tinggi dari orang normal (Muhammad, 2014: 27).

Kedua, dilihat dari keterampilan guru. Faktor yang menjadi kendala ialah masih ada guru yang tidak memiliki latar belakang pendidikan PLB (Pendidikan Luar Biasa). Sehingga guru-guru juga kurang menguasai secara mendalam mengenai teknik-teknik dalam membimbing khususnya bagi anak tunagrahita. Selain itu masih ada juga guru yang tidak mengggunakan prinsip pembelajaran bagi anak tunagrahita. Proses bimbingan ada yang berjalan kurang efektif hal ini dikarenakan beberapa faktor seperti keadaan emosi peserta didik yang tidak baik, waktu yang terbatas, dan penguasaan guru dalam metode menjelaskan yang kurang efektif karena anak tunagrahita ini setiap anak memiliki karakter yang berbeda. Serta keadaan kelas yang kurang efektif, hal ini karena secara teori anak tunagrahita ini adalah 1:5 dimana 1 guru mengajar untuk maksimal 5 peserta didik (Muhammad, 2014: 47). Akan tetapi di SLB Sri Soedewi karena terbatasnya tenaga pengajar dan ruang kelas maka di ruang kelas ada yang melebihi batas maksimum. Selain itu pelatihan untuk guru-guru lebih ke metode pembelajaran, sedangkan untuk pengetahuan tentang seks tu belum ada untuk guru-gurunya.

Ketiga, ditinjau dari Orangtua. Masih banyak orangtua yang tidak ikhlas menerima keadaan anaknya. Ketidak ikhlasan ini terlihat dalam berbagai perilaku orangtua yang mengabaikan, kasar, serta tidak merawat anak sebagaimana 
Peran Guru dalam Mengantisipasi Terjadinya Pelecehan Seksual Terhadap Tunagtahita Ringan semestinya. Sebagaimana dalam al-Qur'an surah at-Taghobun ayat 15 yang berbunyi:

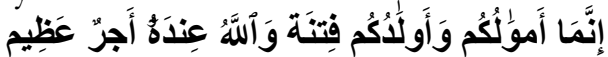

Artinya: Sesungguhnya hartamu dan anak-anakmu hanyalah cobaan (bagimu), dan di sisi Allah-lah pahala yang besar.(QS.at-Taghobun:15)

Bimbingan untuk ABK ini bukan hanya dari guru saja, akan tetapi orangtualah yang lebih memiliki peran yang sangat besar dalam melihat perkembangan peserta didik. Akan tetapi tidak semua orangtua memperhatikan perkembangan anaknya, dengan berbagai alasan seperti karena kesibukan bekerja, terus kurangnya pengetahuan orangtua tentang ABK karena keterbatasan yang di alami oleh anak sering dipandang sebelah mata sehingga ada orangtua yang berpikir bahwa ketika diserahkan ke sekolah maka anaknya menjadi tanggung jawab sekolah sepenuhnya.

Program Pengetahuan Tentang Seks Belum Terprogram dengan Baik (Muhammad, 2014: 47); Pada tahun-tahun sebelumnya pendidikan tentang pengetahuan seks ini sudah diprogramkan dari pemerintahan pusat, yang diberi nama dengan program "Pendidikan Reproduksi". Akan tetapi seiring berjalannya waktu karena terhalang oleh kendala-kendala program tersebut sudah tidak aktif lagi dan terhenti. Pihak sekolah mengalami kendala untuk mengadakan program tentang seks secara tersktruktur. Hal ini dikarenakan adanya kendala-kendala terlebih masalah biaya, kesibukan narasumber dan lain sebagainya. Akan tetapi pihak sekolah memberikan kesempatan kepada instansiinstasi atau lembaga-lembaga yang ingin memberikan pengetahuan tentang seks. Sedangkan di asrama setiap maghrib diadakan pengajian guna untuk menanamkan nilai-nilai agama kepada peserta didik, hal ini khusus bagi peserta didik yang di asrama.

\section{PENUTUP}

Guru harus memiliki kemampuan yang profesional (menguasai ilmu, karakteristik peserta didik, menguasai berbagai pendekatan pembelajaran dan mampu memanajemen kelas dengan baik). Adapun peran guru di SLB Sri Soedewi ialah meliputi peran sebagai: informator, organisator, motivator, inisiator dan fasilitator.

Upaya yang dilakukan oleh guru sebagai pembimbing dalam mencegah terjadinya pelecehan seksual bagi anak tunagrahita meliputi: (1) program pengembangan diri bagi anak tunagrahita, (2) melatih kemandirian, (3) melalui metode pembelajaran, (4) menggunakan prinsip-prinsip pembelajaran tunagrahita (5) bekerjasama dengan instansi-instansi terkait.

Faktor penghambat guru dalam memberikan bimbingan tentang seks kepada peserta didik ditinjau dari berbagai aspek, meliputi: pertama, dintinjau dari 
peserta didik; Berdasarkan pada hambatan-hambatan yang dialami oleh peserta didik tunagrahita di atas, maka masalah tersebut menjadi salah satu kendala yang dialami oleh guru dalam memberikan bimbingan kepada peserta didiknya. Hal ini dikarenakan sering terjadi kesalahan menerima informasi yang diberikan sehingga peserta didik salah menerapkannya. Kedua, dilihat dari keterampilan guru. Berdasarkan penjelasan tersebut, di SLB Sri Soedewi masih banyak guru yang tidak memiliki latar belakang pendidikan PLB. Sehingga guru-guru juga kurang menguasai secara mendalam mengenai teknik-teknik dalam membimbing khususnya bagi anak tunagrahita. Selain itu masih ada juga guru yang tidak mengggunakan prinsip pembelajaran bagi anak tunagrahita. Ketiga, Ditinjau dari Orangtua; di SLB Sri Soedewi tidak semua orangtua mengikuti dan memahami program tersebut. Hal ini dikarenakan dengan berbagai kendala seperti kesibukan orangtua, minimnya pendidikan dan lain sebainya. Sehingga masih ada orangtua yang tidak koperatif dengan perkembangan anaknya. Karena kesalahpahaman dalam pemikiran tentang anak ABK.

Program Pengetahuan Tentang Seks Belum Terprogram dengan Baik; Program tentang pengetahuan tentang seks masih belum berjalan dengan baik dan efektif. Seperti halnya pengadaan seminar dari instansi terkait seperti PKBI, IWAPI dan lain sebagainya hanya dilakukan ketika ada kegiatan-kegiatan tertentu saja, dengankata lain belum terjadwal dan terprogram dengan baik. Hal ini merupakan program dari pemerintahan pusat.

\section{DAFTAR PUSTAKA}

Anonim. (1985). Al-Qur'an dan Terjemahnya (Jakarta: Departemen Agama RI.

Cangara, Hafie. (2012 Cet-13). Ilmu Pengantar Komunikasi. Jakarta: Rajagrafindo Persada.

Desmita. (2015 Cet-9). Psikologi Perkembangan. Bandung : Remaja Rosakarya.

Dwi Yuwono, Ismantoro. (2015). Penerapan Hukum Dalam Kasus Kekerasan Seksual Terhadap Anak. Yogyakarta: Pustaka Yustisia.

Effendi, Muhammad. (2006). Pengantar Psikopedagogik Anak Berkelainan. Jakarta: Bumi Aksara.

Febrisma, Nurliya. (2013). Upaya Meningkatkan Kosa Kata Melalui Metode

Bermain Peran Pada Anak Tunagrahita Ringan (PTK Kelas Dv Di SLB Kartini Batam) E-Jupekhu (Jurnal Imiah Pendidikan Khusus), 1(2), 109-121.

Hazliansyah, "Guru SLB Lecehkan Lima Murid di Garut", di akses 27 Maet 2019 melalui https://www.republika.co.id/berita/duniaislam/tasawuf/12/06/07/nasional/jawa-barat-

nasional/13/04/09/mkyjft-guru-slb-lecehkan-lima-murid-di-garut

Hidayati Rofiah, Nurul. (2015). Bimbingan Belajar Untuk Anak Berkebutuhan

Khusus Di Sekolah Dasar. Prosiding Seminar Nasional dan Call for Papers. Universitas Muhammadiyah Surakarta. 
Peran Guru dalam Mengantisipasi Terjadinya Pelecehan Seksual Terhadap Tunagtahita Ringan

Hidayati Rofiah, Nurul. Bimbingan Belajar Untuk Anak Berkebutuhan Khusus

Di Sekolah Dasar. Aktualisasi Bimbingan Dan Konseling Pada Pendidikan

Dasar Menuju Peserta Didik Yang Berkarakter.

Hikmawati, Fenti. (2011). Bimbingan Konseling. Jakarta: Rajagrafindo Persada.

Humaira, Desni. (2012). Pelaksanaan Pembelajaran Bahasa Indonesia Bagi Anak

Tunagrahita Ringan Kelas III Di SLB Sabiluna Pariaman E-Jupekhu Jurnal Ilmiah Pendidikan Khusus), 1(3), 95-109.

Kustawan, Dedy Dan Yanti Lisnanawati. (2014). Program Pengembangan Diri Untuk

Peserta Didik Tunagrabitta. Direktorat Jenderal Pendidikan Dasar : Kementerian Pendidikan Dan Kebudayaan.

Maslihah, Sri. (2013). Play Therapi Dalam Identifikasi Kasus Kekerasan Seksual Pada Anak. Bandung: Universitas Pendidikan Indonesia.

Muhammad, Hamid. (2014). Pedoman Pelaksanaan Kurikulum Bagi Peserta Didik Berkebutuhan Khusus Di Sekolah Inklusif. Jakarta : Kementerian Pendidikan dan Kebudayaan RI.

Nurzalenawati Elly, Sri. (2013). Meningkatkan Kemampuan Membaca Kata Melalui Metode Fonetis Bagi Anak Tunagrahita Sedang E-Jupekhu Jurnal Ilmiah Pendidikan Khusus), 1 (2), 161-175.

Purwanta, Edi. (2012). Bimbingan Dan Konseling Anak Bekebutuban Khusus. Yogyakarta: Buku Ajar.

Putri, Nadya. (2012). Efektifitas Penggunaan Media Video Untuk Meningkatkan Pengenalan Alat Musik Daerah Pada Pembelajaran Ips Bagi Anak Tunagrahita Ringan Di SDLB 20 Kota Solok E-Jupekhu Jurnal Ilmiah Pendidikan Khusus), 1(2), 318-328.

Ratri Desiningrum, Dinie. (2016 Cet-1). Psikologi Anak Kebutuban Khusus. Yogyakarta : Psikosain.

Renani Pantjastuti, Sri. (2017). Pedoman Pemebalajaran Peserta Didik Tunagrahita. Jakarta: Kementrerian Pendidikan Dan Kebudayaan.

Santoso, Hargio. (2012). Cara Memahami \& Mendidik Anak Berkebutuban Khusus. Yogyakarta: Gosyen Publishing.

Syari Nanda, Devi. (2014). Pelaksanaan Program Transisi Ke Pasca-Sekolah Bagi Tunagrahita Ringan Di SLBN Center Payakumbuh E-Jupekhu (Jurnal Ilmiah Pendidikan Khusus), 3(3), 567-553.

Yasin Al Irsyadi, Fatah dan Yusuf Sulistyo Nugroho. (2015). Game Edukasi Pengenalan Anggota Tubuh Dan Pengenalan Angka Untuk Anak Berkebutuhan Khusus (ABK) Tunagrahita Berbasis Kinect. (Prosiding Snatif Ke-20, 14-20.

Yosiani, Novita. (2014). Relasi Karakteristik Anak Tunagrahita Dengan Pola

Tata Ruang Belajar Di Sekolah Luar Biasa. E-Journal Graduate Unpar Part D - Architecture, 1(20), 111-123.

Zen R.S,dkk. (2006). Sang Guru: Peta Ringkas Hubungan Guru-Murid di pelbagai 
Massuhartono., S.R. Putri.

Tradisi. Yogyakarta: Ekspresi Buku. 